June 1991

\title{
First the Body, Then the Mind
}

Sandra M. Zebrowski, M.D.

Thomas Jefferson University

Follow this and additional works at: https://jdc.jefferson.edu/jeffjpsychiatry

Part of the Psychiatry Commons

Let us know how access to this document benefits you

\section{Recommended Citation}

Zebrowski, M.D., Sandra M. (1991) "First the Body, Then the Mind," Jefferson Journal of Psychiatry. Vol. 9 : Iss. 2 , Article 17.

DOI: https://doi.org/10.29046/JJP.009.2.015

Available at: https://jdc.jefferson.edu/jeffjpsychiatry/vol9/iss2/17

This Article is brought to you for free and open access by the Jefferson Digital Commons. The Jefferson Digital Commons is a service of Thomas Jefferson University's Center for Teaching and Learning (CTL). The Commons is a showcase for Jefferson books and journals, peer-reviewed scholarly publications, unique historical collections from the University archives, and teaching tools. The Jefferson Digital Commons allows researchers and interested readers anywhere in the world to learn about and keep up to date with Jefferson scholarship. This article has been accepted for inclusion in Jefferson Journal of Psychiatry by an authorized administrator of the Jefferson Digital Commons. For more information, please contact: JeffersonDigitalCommons@jefferson.edu. 


\title{
First the Body, Then the Mind
}

\author{
ADULT ANALYSIS AND CHILDHOOD SEXUAL ABUSE \\ Edited by Howard B. Levine \\ The Analytic Press \\ 1990, Hardcover, 231 pp, \$29.95
}

\section{Sandra M. Zebrowski, M.D.}

Sexual abuse of children has in recent years been heralded as an area of concern to psychiatric professionals. An increasing number of patients who present for psychiatric treatment are revealing a history of sexual abuse during childhood or adolescence. Psychiatry has just begun investigating the short and long term psychological sequelae of these traumata, and approaches to treatment are relatively young. For many patients the consequences are severe. One of the most severe cases I have encountered is that of a fellow psychiatric resident who committed suicide during the last year of her residency. She had battled a major depression and severe symptoms of PTSD for a year after uncovering a memory of sexual abuse during psychoanalytic treatment. She was tortured by the experience of having her entire identity built around a defensive posture designed to keep her childhood trauma hidden. I did not understand, then or now, why suicide was the only option for my colleague, but after reading Levine's book and others on the subject, I do appreciate that sexual abuse takes healthy narcissism and an emerging libido and makes them unsafe, frightening and forever deprived territories. Most importantly, it compromises or eradicates the separate identity of another person since its victims are possessed by another. It is one form of what Shengold ' so poignantly calls "soul murder." Howard Levine's Adult Analysis and Childhood Sexual Abuse is in part a response to the need for more synthesized theoretical and clinical material which will aid psychotherapists in the recognition and treatment of the psychopathological sequelae of childhood sexual abuse.

Adult Analysis and Childhood Sexual Abuse is composed of eleven chapters. Three are an introduction and overview; six chapters are devoted to clinical considerations and the psychoanalytic process; and two chapters cover issues of technique. Most of the authors use descriptive, indepth case material as the basis for discussion. While the case material tends to be lengthy compared to the theoretical considerations, the clinical information does help the reader appreciate the range of symptomatology and the degrees of psychopathology in this group as well as the complex and challenging issues that arise in their treatment.

Several of the chapters warrant specific mention. Both chapters written by Steele, and Burland and Raskin are informative overviews of the subject. Steele 
places the sexual abuse of children in a context of dysfunctional family systems where the marital relationship is overdependent and unsatisfying. Superego formation, identity development, and object relations are therefore distorted, but the impact of sexual traumata must be added to the intragenerational and possibly intergenerational pattern of family dysfunction. Burland and Raskin summarize the various symptom manifestations in the treatment of these patients. Their chapter briefly addresses a technique of analyzing conflict around the experience of maternal deprivation in these patients first so that a resultant strong positive transference will allow the ego enough support for the emergence of memories of abuse. Burland and Raskin specifically recommend psychoanalysis as a treatment for adults who were sexually abused as children. Indeed most of the cases written about in this book appear to have received significant benefit from psychoanalytic treatment.

Raphling's chapter deals specifically with the opening phase of analysis. $\mathrm{He}$ outlines how the analyst's stance is of utmost importance with sexually abused patients. Analysands approach the therapy with persistent attempts at uncovering who the analyst is, yet they enter this and every other relationship with mistrust, hypervigilance and a poor sense of boundaries. Patients bring with them a tendency to recreate the past trauma, referred to in later chapters as repetition compulsion, and the analyst must beware of attempts at seduction and address the reality of the incest trauma. Therapists must be especially cautious not to overcompensate for the patient's experience of deprivation.

Bernstein's and Sherkow's chapters deal with the effects of childhood sexual abuse on ego structure and development. Sherkow reports on both adult and child therapy cases and concludes that the implications for developing ego disturbances were seen in children and adults. Bernstein briefly reviews the literature on alterations in ego functioning. She also discusses some differences in ego effects and in countertransference phenomena in mother-son vs father-daughter incest. She introduces, through detailed case illustrations, the complex and shifting transference positions from which the analyst must work. Bernstein emphasizes that there are common ego deficits, such as confusion and doubt of reality, defensive somatizations, and internally disturbed object representations, that signal the possibility of sexual abuse. These signals are crucial since most often the trauma is not reported and the transference and countertransference that quickly develop may lead the analyst into collusion with the patient's denial or other defense mechanisms.

In her chapter "Residues of Incest," Kramer discusses two specific sequelae of childhood sexual abuse. Somatic memories are aversive or disturbing bodily sensations which represent breakthroughs of incompletely repressed incidents or affects. These memories surface at critical moments during analysis as well as during sexual activities. Learning problems often accompany somatic memories as residues of incest. Kramer asserts that the parental admonition not to know or tell coupled with the repression used to cope with the disorganizing memories of incest evolve into a cognitive style that affects the ability to learn new information.

Perhaps the most comprehensive and informative chapters in the book are the 
psychiatrists, to senior psychiatric residents and to others who make use of psychodynamic formulations and psychoanalytic techniques in psychotherapy with their patients.

\section{REFERENCE}

1. Shengold L: Soul Murder, The Effect of Childhood Abuse and Deprivation. New Haven, Yale University Press, 1989 